Preprints of the

Max Planck Institute for

Research on Collective Goods

Bonn 2007/14

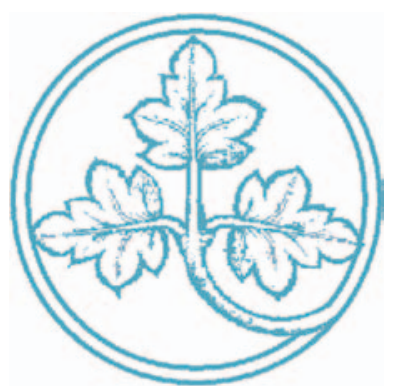

Tacit Collusion

The Neglected

Experimental Evidence

Christoph Engel

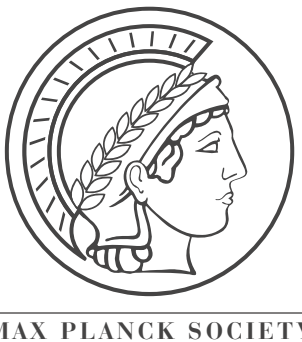




\section{Tacit Collusion The Neglected Experimental Evidence}

Christoph Engel

September 2007

Max Planck Institute for Research on Collective Goods, Kurt-Schumacher-Str. 10, D-53113 Bonn http://www.coll.mpg.de 


\section{Christoph Engel}

I. The Issue 2

II. Doctrine 2

III. Methodology of the Meta-Study 4

IV. Improving the Merger Guidelines 5

1. Factors Listed in the Merger Guidelines 5

a. Number of Suppliers 5

b. Stability 6

c. Product Homogeneity $\quad 7$

$\begin{array}{ll}\text { d. Symmetry } & 8\end{array}$

e. Transparency 8

2. Factors Neglected by the Guidelines 9

a. Gains from Collusion $\quad 9$

b. Experience $\quad 9$

c. Strategic Variable 10

d. Sequential Interaction 12

e. Active Demand 12

3. Relative Weight 13

V. Deciding Individual Cases: Airtours 15

1. Stylized Facts $\quad 15$

2. Limited Fit of Experimental Data 15

3. A Statistically Valid Indirect Approach 16

$\begin{array}{ll}\text { VI. Conclusion } & 17\end{array}$ 


\section{The Issue}

Normally, hard scientific evidence on legal issues is a seriously scarce commodity. More than one empirical publication on a precisely defined doctrinal question is a rare event. Against this backdrop, a problem in antitrust is salient. Both in the US and in Europe, antitrust authorities prohibit merger not only if the merged entity, in and of itself, is no longer sufficiently controlled by competition. The authorities also intervene if, post merger, the market structure has changed such that "tacit collusion" becomes disturbingly more likely. Antitrust authorities rely on game theory to assess this risk (Ivaldi, Jullien et al. 2003). Yet on this prognostic question, economists have also, for more than 50 years, been doing experiments. Almost any conceivable determinant of higher or lower collusion has been tested. This solid body of evidence is untapped by the legal community. It seems that the antitrust authorities are not even aware of the fact that one of their thorniest empirical questions has already been thoroughly investigated by a neighbouring discipline.

This paper makes the evidence available. It standardises the findings by way of a meta-study, and it matches the experimental findings as closely as possible to doctrine. In preparation, the key concepts of the doctrine of tacit collusion in the US and in Europe are reported (II), and the methodology of the meta-study is explained (III). Antitrust can capitalise on the experimental evidence at two levels. It is most helpful in evaluating and further developing the guidelines that authorities on both sides of the Atlantic have issued for assessing the "co-ordinated effects" of mergers. Currently, based on previous experience and theory, the authorities use checklists (US Merger Guidelines; ${ }^{1}$ EU Merger Guidelines ${ }^{2}$ ). The individual criteria in these lists can be checked back against the experimental evidence. More importantly even, by calculating effect sizes the criteria can be ranked according to their predictive power (IV). Individual cases combine these criteria in idiosyncratic ways. Although data on 510 parameter constellations are included in the meta-study, an experimental result on exactly the parameter combination of a given case is often not available. Based on the meta-study, it is possible to say something about interaction effects. But the data on multiple interactions is usually not significant. Nonetheless, the meta-study is also useful for deciding individual cases. It provides additional evidence on which features of the case make it particularly likely that the respective reduction in the number of competitors is or is not a normative problem. This is demonstrated with respect to the European landmark case on tacit collusion, the Airtours ruling (V).

\section{Doctrine}

Under section 7 of the Clayton Act, mergers are prohibited if their effect "may be substantially to lessen competition, or to tend to create a monopoly" (15 U.S.C. 18). Under section 1 of the

1 Department of Justice, Federal Trade Commission, Antitrust Division, 1992 Horizontal Merger Guidelines of September 10, 1992, 57 FR 41552, preface.

2 Guidelines on the Assessment of Horizontal Mergers under the Council Regulation on the Control of Concentrations between Undertakings, OJ 2004 C 31/5. 
Sherman Act, they are prohibited if they constitute a "contract, combination [...], or conspiracy in restraint of trade" (15 U.S.C. 1). Under section 5 of the Federal Trade Commission Act, they are prohibited if they constitute an "unfair method of competition" (15 U.S.C. 45). Both the Antitrust Division of the Department of Justice and the Federal Trade Commission have jurisdiction to intervene. In order to increase predictability, in 1992 both authorities have issued joint guidelines on the treatment of horizontal mergers. While most of these guidelines have been a restatement of court decisions and administrative practice, the section on potential coordinated and unilateral effects of mergers was meant to innovate (US Merger Guidelines, preface).

The guidelines stress that the anti-competitive effects of merger are not confined to increased market power for the new commercial unit (US Merger Guidelines, \#2.0). The Agency will also "examine the extent to which post-merger market conditions are conducive to reaching terms of coordination, detecting deviations from those terms, and punishing such deviations”. It will intervene into the "lessening of competition through coordinated interaction" (US Merger Guidelines, \#2.1). To that end, the Agency expressly engages in prediction, based on information about market conditions, previous conduct of the merging firms, and theory (US Merger Guidelines, \#2.11 and \#2.12).

In Europe, under Art. 3 II of the Merger Regulation, “a concentration which would significantly impede effective competition, in the common market or in a substantial part of it, in particular as a result of the creation or strengthening of a dominant position, shall be declared incompatible

with the common market" (OJ 2004 L 24/1). According to the case law of the European Court of Justice, the test includes situations of "collective dominance". In the Airtours case of $2002^{3}$, coordinated effects have been centre stage, with a rich echo in academic writing (Motta 2000; Christensen and Rabassa 2001; Haupt 2002; Overd 2002; Stroux 2002; Guerrero 2003; Nikpay and Houwen 2003; Scott 2003; Spink and Ong 2003; Veljanovski 2004; Kokkoris 2005). But the doctrinal concept is as old as the Nestlé/Perrier case of 1992. ${ }^{4}$ It has been approved by the European Court of Justice in the Kali und Salz case of $1998^{5}$ (Perez 1998; Ysewyn and Caffarra 1998).

In Airtours, the European Court of First Instance has held that a merger may be prohibited if, in light of "the relationship of interdependence [...] the parties [...] are in a position to anticipate one another's behaviour and are therefore strongly encouraged to align their conduct in the market, in particular in such a way as to maximise their joint profits by restricting production with a view to increasing prices. In such a context, each trader is aware that highly competitive action on its

3 Court of First Instance, 6 June 2002, Airtours plc v Commission of the European Communities, European Court Reports 2002 II 2585.

4 Commission Decision, 22 July 1992, OJ 1992 L 356/1; see also Commission Decision, 14 December 1993, OJ 1994 L 186/38, Kali+Salz/MdK/Treuhand.

$5 \quad$ European Court of Justice, 31 March 1998, European Court Reports 1998 I 1519, para. 221; see also European Court of First Instance, 25 March 1999, European Court Reports 1999 II 753, Gencor and on this case Albors-Llorens in Cambridge Law Journal (2000); Commission Decision, 26 October 2004, OJ 2005 L 218/6, Oracle/People Soft and on this case Pflanz in European Competition Law Review (2005). 
part designed to increase its market share (for example a price cut) would provoke identical action by the others, so that it would derive no benefit from its initiative” (ECJ Airtours, \#60).

"Three conditions are necessary for a finding of collective dominance [...]: first, each member of the dominant oligopoly must have the ability to know how the other members are behaving in order to monitor whether or not they are adopting the common policy [...]; second, the situation of tacit coordination must be sustainable over time [...]; third, to prove the existence of a collective dominant position to the requisite legal standard, the Commission must also establish that the foreseeable reaction of current and future competitors, as well as of consumers, would not jeopardise the results expected from the common policy” (ECJ Airtours, \#62). These conditions have almost literally found their way into the 2004 Horizontal Merger Guidelines of the European Commission (EU Merger Guidelines, \#22, 39, 41) (see also Etter 2000; Briones and Padilla 2001).

\section{Methodology of the Meta-Study}

(Almost) every experimental paper on oligopoly reports one finding: which has been the effect of the respective treatment on the strategic variable of the oligopolists (which is normally either price or quantity)? For the meta-study, the mean over all instances of interaction is taken. The absolute number is normalised across experiments by comparing it to two benchmarks: the Walrasian and the collusive outcome, as illustrated in Figure 1. The Walrasian equilibrium is the market outcome where marginal industry cost, and hence marginal supply, equals marginal demand. If buyers maximise utility, and sellers maximise profit, at this point, the market clears.

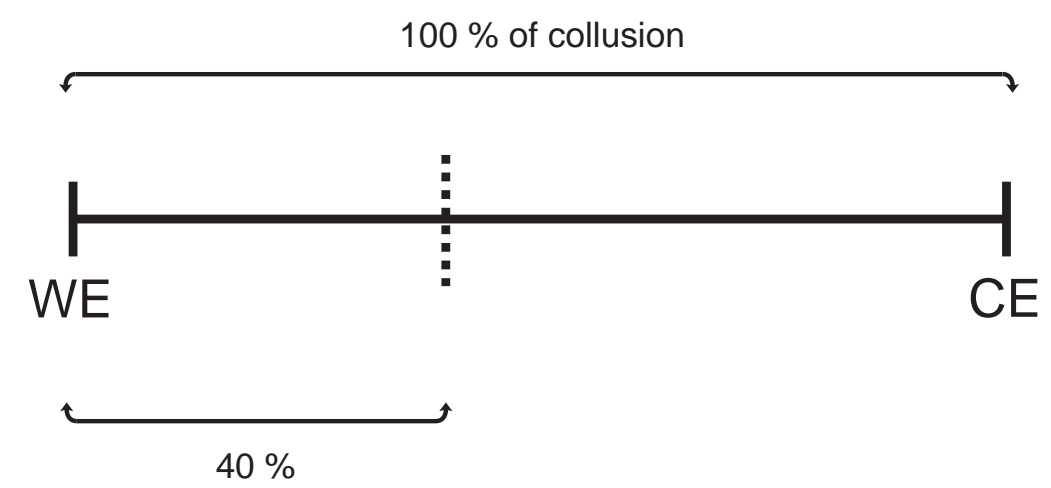

Figure 1 Normalization

The distance between the Walrasian equilibrium WE and the collusive equilibrium CE is defined as $100 \%$ of collusion. The dashed line is an example for the reported value of the strategic variable, say price. In the example, this value lies $40 \%$ above the Walrasian level. Of course, the reported value may be below the Walrasian equilibrium. In that case, the degree of collusion is indicated by a negative number. If the strategic variable is quantity, a small number means a high 
degree of collusion. To capture this, the reported quantity is normalised by how much it lies below, not above the Walrasian expectation ${ }^{6}$.

There is a total of 154 experimental papers with a pertinent topic ${ }^{7}$. For a number of reasons, 47 papers had to be excluded from the meta-study ${ }^{8}$. In preparation of the study, frequently the benchmarks and the means had to be calculated. For the study, all data is pooled ${ }^{9}$. It is tested for significance by way of ANOVA ${ }^{10}$.

\section{Improving the Merger Guidelines}

Some factors listed in the US or EU merger guidelines do not have a direct analogue in the experimental literature. For instance, there are no experiments with one firm being a "maverick" (US Merger Guidelines, \#2.12; EU Merger Guidelines, \#42). Other factors could not be sufficiently standardised to be integrated into the meta-study. For instance, the antitrust authorities are more critical if there is evidence that market participants have already been engaged in collusion in the past (US Merger Guidelines, \#2.1; EU Merger Guidelines, \#43). In a way, this is mirrored by time series information. Experimenters report how collusion develops over several rounds of repetition. In this meta-study, however, only the mean degree of collusion over all rounds of interaction is taken into account. Many factors checked by the antitrust authorities are, however, also tested experimentally. The experimental evidence shows how much collusion is to be expected if one of the tested factors is present (1). And there is data on factors that are relevant for the degree of collusion in experiments, but that are not listed in the merger guidelines, or get short shrift (2). Most importantly, by calculating effect sizes, the factors taken into account in predicting future collusion may be ranked (3). In all these ways, the merger guidelines may be checked back against an additional source of evidence, and they may be improved in light of this.

\section{Factors Listed in the Merger Guidelines \\ a. Number of Suppliers}

Merger control prevents the number of suppliers in a market from being reduced. All experiments had to specify this number. "The reduction in the number of firms in a market may, in itself, be a factor that facilitates coordination” (EU Merger Guidelines, \#42). Experimental find-

In a companion paper, the data is normalized a second time with respect to the distance between the Nash equilibrium, and the collusive equilibrium, Engel in Journal of Competition Law and Economics (2007). That way, one learns how well game theory predicts the results.

7 For the bibliography see the companion paper ibid.in .

8 For detail see the companion paper ibid.in .

9 The companion paper also reports data only from those papers that expressly tested for the respective effect, and from a reduced sample. In the latter sample all data is missing that, in whichever way, is "unusual" (with the paper specifying the reasons for this). 
ings support this view. As demonstrated by the linear regression in Table 1, there is a clear negative relation between the number of suppliers and the degree of collusion.

\begin{tabular}{|lr|lr|r|}
\hline B & Standard Deviation & Beta & $-0,31$ \\
\hline Constant & $-4,42$ & \multicolumn{2}{|c|}{0,61} & \\
\hline & Standard Deviation & 2,98 & \\
\hline adj. $R^{2}$ & 53,71 & & & \\
\hline & & & & \\
\hline
\end{tabular}

Table 1

Number of Suppliers: Linear Regression

$p<0,001$ (both for Const and Beta)

As Table 2 shows, in small markets, the general relation also holds if the number of suppliers is reduced by just one. In larger (experimental) markets, there is more variance (but the number of observations is so small, and the standard deviations are so large here, that this variance might be due to chance).

\begin{tabular}{|l|r|l|r|}
\hline & $\begin{array}{l}\text { mean degree of } \\
\text { collusion }\end{array}$ & $\begin{array}{l}\text { standard } \\
\text { deviation }\end{array}$ & $\begin{array}{l}\text { number of } \\
\text { observations }\end{array}$ \\
\hline size 2 & 62,30 & 39,44 & 163 \\
\hline size 3 & 42,70 & 34,81 & 79 \\
\hline size 4 & 14,59 & 33,58 & 142 \\
\hline size 5 & 37,95 & 30,80 & 20 \\
\hline size 6 & 18,05 & 28,26 & 37 \\
\hline size 7 & 1,00 & 13,78 & 6 \\
\hline size 8 & 14,95 & 25,93 & 19 \\
\hline size 10 & 26,00 & & 4 \\
\hline size 11 & 8,50 & 1,73 & 2 \\
\hline size 16 & 38,00 & 32,53 & 4 \\
\hline size 22 & 6,75 & 29,08 & 2 \\
\hline size 25 & $-11,00$ & 14,14 & \\
\hline
\end{tabular}

Table 2

Number of Suppliers: ANOVA

$p<0,001$

\section{b. Stability}

"It is easier to coordinate on a price when demand and supply conditions are relatively stable than when they are continuously changing” (EU Merger Guidelines, \#45). The experiments have not tested stability directly. However there is a relatively close proxy in the number of rounds that experimental subjects have interacted. There is a (weak) positive relationship between the degree of collusion and the number of rounds, as demonstrated by Table 3 . 


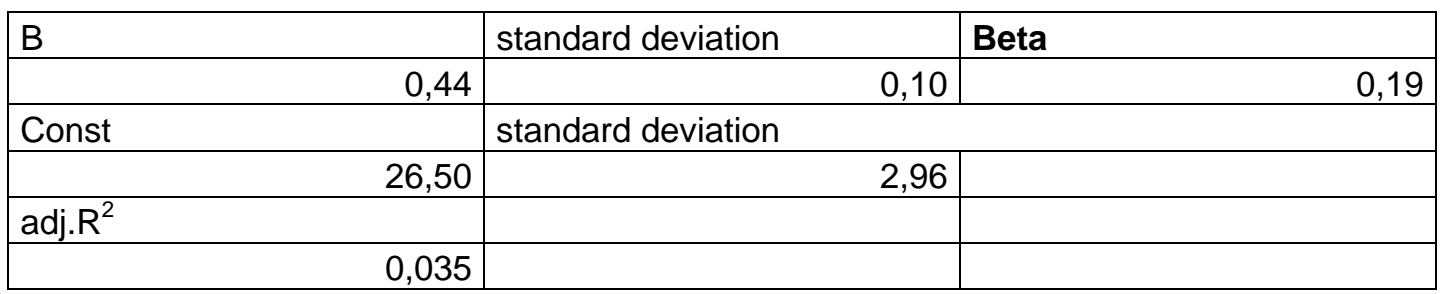

Table 3

Duration: Linear Regression

$p<0,001$ (both for Const and Beta)

"In markets where innovation is important, coordination may be more difficult" (EU Merger Guidelines, \#45). Surprisingly, the experimental findings are squarely opposed to the conjecture, as shown in Table 4. In these experiments, innovation had typically been implemented by the costly possibility to buy a lottery. With some predefined probability, this lottery reduced production cost for those subjects who had bought it.

\begin{tabular}{|l|l|l|l|}
\hline & $\begin{array}{l}\text { mean degree of } \\
\text { collusion }\end{array}$ & $\begin{array}{l}\text { standard } \\
\text { deviation }\end{array}$ & $\begin{array}{l}\text { number of } \\
\text { observations }\end{array}$ \\
\hline no innovation & 34,94 & 36,51 & 453 \\
\hline innovation & 62,77 & 81,89 & 26 \\
\hline
\end{tabular}

Table 4

Process Innovation

$p=0,001$

\section{c. Product Homogeneity}

"It is [...] easier to coordinate on a price for a single, homogeneous product" (EU Merger Guidelines, \#45; cf. US Merger Guidelines, \#2.11). If collusion is measured as the relative deviation from the Walrasian equilibrium, theory would expect a smaller deviation when products are homogeneous. Heterogeneity leads to monopolistic competition (Chamberlin 1933). This is also what one finds in experiment ${ }^{11}$, as shown in Table 5.

\begin{tabular}{|l|l|l|l|}
\hline & $\begin{array}{l}\text { mean degree of } \\
\text { Collusion }\end{array}$ & $\begin{array}{l}\text { Standard } \\
\text { deviation }\end{array}$ & $\begin{array}{l}\text { number of } \\
\text { observations }\end{array}$ \\
\hline homogeneous product & 30,04 & 40,17 & 419 \\
\hline heterogeneous product & 67,46 & 26,04 & 91 \\
\hline
\end{tabular}

Table 5

Product Homogeneity

$p=0,001$

11 Since, with heterogeneous products, price and quantity are not informative, in this case profit is taken as the dependant variable. 


\section{d. Symmetry}

"Firms may find it easier to reach a common understanding on the terms of coordination if they are relatively symmetric” (EU Merger Guidelines, \#48; cf. US Merger Guidelines, \#2.1). The experimental support for this claim is at best weak, as one sees in Table 6.

\begin{tabular}{|l|r|l|l|}
\hline & $\begin{array}{l}\text { mean degree of } \\
\text { collusion }\end{array}$ & $\begin{array}{l}\text { standard } \\
\text { deviation }\end{array}$ & $\begin{array}{l}\text { number of } \\
\text { observations }\end{array}$ \\
\hline symmetry & 39,11 & 41,76 & 315 \\
\hline asymmetry & 31,33 & 37,98 & 164 \\
\hline
\end{tabular}

Table 6

Symmetry

$p=0,047$

\section{e. Transparency}

"Successful coordinated interaction entails [...] an ability to detect and punish deviations" (US Merger Guidelines, \#2.1). "If key information about specific transactions or individual price or output levels is available routinely to competitors, it may be difficult for a firm to deviate secretly” (US Merger Guidelines, \#2.12; cf. EU Merger Guidelines, \#49). Experimenters have split this up, and separately checked the effect of ex ante information, and of feedback. Both have a pronounced effect on collusion, as demonstrated by Table 7 and Table 8 . The better subjects are informed, the more they collude.

\begin{tabular}{|l|l|l|r|}
\hline & $\begin{array}{l}\text { mean degree of } \\
\text { collusion }\end{array}$ & $\begin{array}{l}\text { Standard } \\
\text { deviation }\end{array}$ & $\begin{array}{l}\text { number of } \\
\text { observations }\end{array}$ \\
\hline reduced ex ante information & 19,98 & 39,82 & 126 \\
\hline partial ex ante information & 38,23 & 31,79 & 90 \\
\hline full ex ante information & 52,75 & 42,02 & 180 \\
\hline
\end{tabular}

Table 7

Ex ante Information

$p<0,001$

\begin{tabular}{|l|r|l|r|}
\hline & $\begin{array}{l}\text { mean degree of } \\
\text { collusion }\end{array}$ & $\begin{array}{l}\text { standard } \\
\text { deviation }\end{array}$ & $\begin{array}{l}\text { number of } \\
\text { observations }\end{array}$ \\
\hline reduced feedback & 6,52 & 30,58 & 79 \\
\hline partial feedback & 37,54 & 35,56 & 258 \\
\hline full feedback & 57,40 & 45,57 & 111 \\
\hline
\end{tabular}

Table 8

Feedback

$p<0,001$

The distinction between full and partial ex ante information or feedback is clearcut. If subjects are fully informed, they are able to calculate their competitors' profits. With partial information, 
they are only able to anticipate their own profit. The reduced information category is less strictly defined. It encompasses all situations where subjects receive yet less information. Often this means that they have no full knowledge of demand. Sometimes, there is cost uncertainty. ${ }^{12}$

\section{Factors Neglected by the Guidelines}

\section{a. Gains from Collusion}

The more experimental subjects have to gain, the more they collude. In the lab, how much sellers have to gain results from the shape of the induced demand and supply curves. Table 9 distinguishes three situations: In the Walrasian equilibrium, producer and consumer rent are about the same. Or one side gets more. If the supply curve is steep, and the demand curve is flat, most gains are with suppliers anyhow ("producer surplus”). The opposite holds if marginal cost is constant ${ }^{13}$, while demand decreases in price (“consumer surplus”). In such a situation, collusion pays highly. Consequently, collusion is the more likely, the more it hurts the opposite market side.

\begin{tabular}{|l|r|r|r|}
\hline & $\begin{array}{l}\text { mean degree } \\
\text { of collusion }\end{array}$ & $\begin{array}{l}\text { standard } \\
\text { deviation }\end{array}$ & $\begin{array}{l}\text { number of } \\
\text { observations }\end{array}$ \\
\hline producer surplus & 11,20 & 38,74 & 25 \\
\hline symmetric surplus & 22,90 & 32,16 & 132 \\
\hline consumer surplus & 44,56 & 41,92 & 315 \\
\hline
\end{tabular}

Table 9

Sensitivity to Gains from Collusion

$p<0,001$

\section{b. Experience}

From the very beginning, experimenters have tested whether experienced subjects behave differently. If one only looks at the main effect, as reported in Table 10, the message seems comforting: experienced subjects collude less. Antitrust authorities may safely assume that the members of a narrow oligopoly have considerable experience in interacting with each other.

\begin{tabular}{|l|l|l|l|}
\hline & $\begin{array}{l}\text { mean degree of } \\
\text { collusion }\end{array}$ & $\begin{array}{l}\text { standard } \\
\text { deviation }\end{array}$ & $\begin{array}{l}\text { number of } \\
\text { observations }\end{array}$ \\
\hline no experience & 38,11 & 41,31 & 404 \\
\hline experience & 27,47 & 35,71 & 75 \\
\hline
\end{tabular}

Table 10

Experience: Main Effect

12 Details are specified in the database that is behind the meta-study. It is available upon request.

13 There are no experiments where marginal cost decreases if more units are sold. 
However, this would be a misleading policy conclusion. If one checks for the interaction between experience and the opportunity to communicate with each other, the picture changes dramatically. With no communication, experienced subjects collude less. But if they are given a chance to talk, collusion jumps up, as shown by Table 11.

\begin{tabular}{|l|l|l|lr|}
\hline & $\begin{array}{l}\text { mean degree of } \\
\text { collusion }\end{array}$ & $\begin{array}{l}\text { Standard } \\
\text { deviation }\end{array}$ & $\begin{array}{l}\text { number of } \\
\text { observations }\end{array}$ \\
\hline & no experience & no experience & no experience & 368 \\
\hline no communication & 38,33 & 40,36 & 36 \\
\hline communication & 35,92 & 50,60 & 69 \\
\hline & experience & experience & experience \\
\hline no communication & 23,52 & & 34,40 & 6 \\
\hline communication & 72,83 & 9,75 & & \\
\hline
\end{tabular}

Table 11

Interaction Experience - Communication

$p=0,005$

One gets the same picture if one tests for the interaction between experience and a chance to agree on market behaviour, as in Table 12.

\begin{tabular}{|l|r|l|lr|}
\hline & $\begin{array}{l}\text { mean degree of } \\
\text { collusion }\end{array}$ & Standard deviation & \multicolumn{2}{l|}{$\begin{array}{l}\text { number of observati- } \\
\text { ons }\end{array}$} \\
\hline & no experience & no experience & no experience \\
\hline no agreement & 37,68 & 40,15 & 379 \\
\hline agreement & 44,76 & 56,61 & 25 \\
\hline & experience & experience & experience \\
\hline no agreement & 24,59 & 34,49 & 41 \\
\hline agreement & 78,50 & 5,45 & 4 \\
\hline
\end{tabular}

Table 12

Interaction Agreement - Communication

$p=0,036$

This is troubling news for antitrust law. It is easy for the legal order to prohibit binding agreements. It suffices to say in a statute that cartels are not enforceable in law. It, however, is next to impossible to prevent the members of an oligopoly to talk to each other. Comparing Table 11 with Table 12, one sees that this is all experienced subjects need to get collusion going.

\section{c. Strategic Variable}

In theory, and in the experimental lab, the strategic variable is fixed. Suppliers either use price as the strategic variable ("Bertrand competition”), or quantity (“Cournot competition”). In theory, this makes a huge difference. The difference is the larger, the smaller the market. If suppliers compete in price, and if marginal cost is constant, the Walrasian and the Nash equilibrium coincide (Bertrand 1883). Although collusion would be profitable, suppliers are unable to bring it 
about since they are pitted against each other in a prisoner's dilemma. If they compete in quantity, however, the non-cooperative solution is bounded away from the point where the market clears. In duopoly, the difference between the Nash and the Walrasian equilibrium is largest (Cournot 1838).

In the lab, the difference is much smaller than theory expects. If one compares market outcomes to the respective Nash prediction, it becomes clear that the experimental data fits the Cournot model pretty well, whereas subjects collude much more than the Bertrand model predicts ${ }^{14}$. Although the effect is thus attenuated, there is still a net difference between price and quantity competition, as shown by Table 13.

\begin{tabular}{|c|c|c|c|}
\hline & $\begin{array}{l}\text { mean degree of } \\
\text { collusion }\end{array}$ & $\begin{array}{l}\text { standard } \\
\text { deviation }\end{array}$ & \begin{tabular}{|l|} 
number of \\
observations
\end{tabular} \\
\hline quantity & 49,43 & 31,19 & 127 \\
\hline price & 30,36 & 36,71 & 338 \\
\hline
\end{tabular}

Table 13

Strategic Variable

$p<0,001$

The EU Guidelines allude to the point: "Coordination may take various forms. In some markets, the most likely coordination may involve keeping prices above the competitive level. In other markets, coordination may aim at limiting production or the amount of new capacity brought to the market” (EU Merger Guidelines, \#40), without making much out of the difference. This reticence is probably due to the difficulty of saying in practice which is the strategic variable.

In principle, there is a good proxy. If extending capacity is not feasible in the short run, or if this is prohibitively costly, aggressive pricing does not pay. Price cuts attract more demand, but the supplier is unable to exploit the opportunity to her advantage (Kreps and Scheinkman 1983). Consequently, in such markets, competition must focus on quantity. The antitrust authorities will often be in a position to determine whether the cost of extending capacity is pronounced. Yet unfortunately, the experimental evidence in Table 14 does not make it advisable to use this proxy. With constrained capacity, experimental subjects stay much closer to the Walrasian equilibrium. This is the opposite of the expectation resulting from the Kreps/Scheinkman model.

\begin{tabular}{|l|l|l|l|}
\hline & $\begin{array}{l}\text { mean degree of } \\
\text { collusion }\end{array}$ & $\begin{array}{l}\text { Standard } \\
\text { deviation }\end{array}$ & $\begin{array}{l}\text { number of } \\
\text { observations }\end{array}$ \\
\hline unconstrained & 54,09 & 38,98 & 252 \\
\hline constrained & 16,86 & 32,74 & 227 \\
\hline
\end{tabular}

Table 14

Capacity Constraints

$p<0,001$

14 For detail and the additional methodology necessary for this test, see the companion paper, Engel in Journal of Competition Law and Economics (2007). 


\section{d. Sequential Interaction}

In narrow markets, it happens that one seller has a chance to commit to quantity or price, in advance of her competitors. If products are homogeneous, theory then predicts a smaller deviation from the Walrasian equilibrium if firms compete in quantity (Stackelberg 1934). If they compete in price and if marginal cost is constant, there should be no deviation from the Walrasian equilibrium. Since, in this setting, sellers are playing a prisoner's dilemma, the switch to sequential interaction is irrelevant, at least in the stage game, which is the unit of reference for all experimental findings. This is due to the fact that defection (i.e. setting the market clearing price) is a dominant strategy for either of them. Experiments yield the opposite result, as shown in Table 15. Sequential interaction leads to more collusion throughout.

\begin{tabular}{|c|c|c|c|}
\hline & $\begin{array}{l}\text { mean degree of } \\
\text { collusion }\end{array}$ & $\begin{array}{l}\text { standard } \\
\text { deviation }\end{array}$ & $\begin{array}{l}\text { number of } \\
\text { observations }\end{array}$ \\
\hline simultaneous & 35,00 & 36,65 & 421 \\
\hline sequential & 46,91 & 61,79 & 58 \\
\hline
\end{tabular}

Table 15

Simultaneous - Sequential Interaction

$\mathrm{p}=0,036$

\section{e. Active Demand}

Oligopoly experiments are designed to learn more about the behaviour of sellers. This explains that buyers are usually replaced by a computer. This computer is programmed as a non-strategic actor. It simply represents the demand curve. This apparently innocent way of saving experimental resources, and of gaining full control over the opposite market side, has a dramatic influence on collusion. When subjects know that they are playing against human buyers, collusion rates plummet, as shown by Table 16.

\begin{tabular}{|l|l|l|l|}
\hline & $\begin{array}{l}\text { mean degree of } \\
\text { collusion }\end{array}$ & $\begin{array}{l}\text { standard } \\
\text { deviation }\end{array}$ & $\begin{array}{l}\text { number of } \\
\text { observations }\end{array}$ \\
\hline computer buyer & 42,98 & 40,02 & 393 \\
\hline human buyer & 6,60 & 28,26 & 86 \\
\hline
\end{tabular}

Table 16

Computer - Human Buyer

$\mathrm{p}<0,001$

There could be several reasons for the effect. For instance, experimental subjects might be reluctant to inflict harm on their peers. And in reality, oligopolists rarely trade with computers. However, an alternative explanation also matters for antitrust practice. Sellers might become more cautious if they expect the demand side of the market to be active. 
The evidence on the importance of the trading institution given in Table 17 supports this explanation. The majority of oligopoly experiments uses the posted offer institution. Each seller is free to post a price. Buyers shop around, or efficient rationing does the shopping for them. This rule makes buyers almost passive. Consequently, collusion is highest. The effect becomes even stronger in the "posted Diamond" treatment. This treatment is meant to test the model by (Diamond 1971). This is implemented by making shopping costly for buyers. All other trading institutions yield collusion rates far below this level. If participants at both sides of the market have an opportunity to submit a sealed bid, there is still a small amount of collusion. If they negotiate individually, collusion is already close to zero. In a double auction, average collusion falls below the Walrasian prediction. Under this rule, every higher bid by a buyer replaces all previous lower bids. Likewise every lower bid by a seller replaces all previous higher ones ${ }^{15}$.

\begin{tabular}{|l|r|l|l|}
\hline & $\begin{array}{l}\text { mean degree of } \\
\text { collusion }\end{array}$ & $\begin{array}{l}\text { Standard } \\
\text { deviation }\end{array}$ & $\begin{array}{l}\text { number of } \\
\text { observations }\end{array}$ \\
\hline other trading institution & 9,19 & 29,20 & 16 \\
\hline posted & 48,67 & 38,41 & 339 \\
\hline posted Diamond & 45,19 & 24,63 & 16 \\
\hline sealed bid & 4,53 & 29,11 & 17 \\
\hline negotiation & 1,29 & 11,57 & 14 \\
\hline double auction & $-0,06$ & 26,20 & 77 \\
\hline
\end{tabular}

Table 17

Trading Institution

$p<0,001$

\section{Relative Weight}

The experimental evidence does not only point antitrust practice to additional factors that make the risk of collusion more serious. Its most valuable contribution is quantitative. It is possible to estimate the relative weight of all factors that increase collusion. The higher this weight, the more attentive antitrust authorities should be to the presence, or the absence, of the respective factor. To that end, in Table 18 effect sizes are calculated. Note that the effect size does not merely measure the difference in means, with and without the factor that increases collusion. Instead, effect sizes take the degree of variance into account. The effect size is the larger the more clearly the respective independent variable splits the sample into distinct groups. $\eta^{2}$ measures how much of the variance in the sample is explained by a certain independent variable. 


\begin{tabular}{|l|r|}
\hline & $\eta^{2}$ \\
\hline duration & 0,289 \\
\hline number of suppliers & 0,279 \\
\hline trading institution & 0,259 \\
\hline constant/decreasing supply & 0,229 \\
\hline unconstrained/constrained capacity & 0,210 \\
\hline feedback & 0,173 \\
\hline homogeneous product/substitute & 0,121 \\
\hline computer/human buyer & 0,118 \\
\hline ex ante information & 0,117 \\
\hline $\begin{array}{l}\text { consumer/symmetric/producer } \\
\text { surplus }\end{array}$ & 0,078 \\
\hline strategic variable & 0,055 \\
\hline innovation/no & 0,024 \\
\hline sequential/simultaneous & 0,009 \\
\hline experience/no & 0,009 \\
\hline symmetry/asymmetry & 0,008 \\
\hline
\end{tabular}

Table 18

Effect Sizes

This is important news for antitrust practice. The only factor that is under the direct influence of antitrust authorities, i.e. the number of firms in the industry, is also the second most relevant. It explains $27,9 \%$ of the variance, which corresponds to a correlation of 0,528 . Antitrust authorities have good reason to be vigilant if a merger reduces the number of firms, even if the new entity does not in and of itself hold a dominant position.

There is a huge difference in effect size between factors that antitrust authorities currently consider. Feedback is more than 20 times more important than symmetry. If one takes the number of repetitions as a measure of stability, stability is even 36 times as important as symmetry. Feedback matters much more than ex ante information. Product homogeneity is important, process innovation is not.

Finally, the relevance of the factors currently neglected by antitrust authorities may be calibrated. The biggest neglect is trading institutions. It is as important for collusion as is stability, or the number of firms in a market. Also, the fact that capacity is not constrained has a strong effect. Contrary to this, the fact that interaction is sequential, or that subjects are experienced, is negligible. If the activity of the demand side results from nothing else than the fact that there have been human buyers, the effect is only mid-sized. The effect of the strategic variable is even smaller. Most interesting is the data concerning gains from collusion. The most direct way of measuring them is surplus. However the variable that only measures producer rent, i.e. the slope of the supply curve, is three times as informative. Apparently, at least experimental subjects do not (subconsciously) calculate through all the elements needed for profit maximisation. They seem to take the slope of the supply curve as a proxy. 


\section{Deciding Individual Cases: Airtours}

The experimental evidence is thus directly relevant for double checking and improving the merger guidelines on both sides of the Atlantic. It is less easy, but still useful, to rely on this evidence when deciding individual cases. The possibilities, and the limits, of this application shall be illustrated with respect to the European landmark case, the Airtours case. To that end, the facts of the case are summarised (1). There is no experiment with exactly these features (2). But in more indirect ways, the experimental evidence can nonetheless help the antitrust authorities in making better decisions (3).

\section{Stylized Facts}

The European Commission had defined the relevant market to be the English market for shorthaul foreign package holiday (\#4). At the time of the decision, there were four large providers. In the Commission's numbers, these four providers controlled $79 \%$ of sales (\#66). The remaining market participants were not only small. They also lacked vertical integration with airlines and travel agents (\#66). In the short run, capacity was fixed. It had to be contracted one and a half years in advance (\#80, \#158), meaning that providers competed in quantity. Demand was relatively volatile (\#140), but had no countervailing power (\#121). Several issues were in dispute. How easy was it for providers to observe capacity decisions of their competitors (\#180)? Was retaliation feasible, should one firm ignore tacit collusion (\#183)? How high were barriers to entry (\#208)?

Airtours merged with First Choice. The new firm controlled 32\% of the market, with the remaining large providers controlling $27 \%$ and $20 \%$, respectively. This makes for a HerfindahlHirschman Index (HHI) of 2153. An HHI $>1800$ is regarded to be very critical (US Merger Guidelines, \#1.5).

\section{Limited Fit of Experimental Data}

Although there is a total of 510 published experiments on oligopoly, none of them has exactly the features of the Airtours case. Table 19 reports the mean degree of collusion if one progressively narrows the sample, to come as close as possible to the Airtours case. Note, however, three limitations. To get as far as this, the data is pooled for markets with up to three, and for those with more than three suppliers. One relevant feature of the case, market entry, is not covered. Nobody has ever tested an open market in an oligopoly setting. Most importantly, each new feature reduces the number of experiments that remain in the sample. In statistical terms, the last step tests a 6x6 interaction effect. Not surprisingly, the findings are not significant. Actually, the only significant finding is the main effect for markets of up two, versus more than, three firms. 


\begin{tabular}{|l|r|r|r|r|r|r|}
\hline & firms (2-3) & $\begin{array}{l}+ \text { quanti- } \\
\text { ty }\end{array}$ & $\begin{array}{l}+ \\
\text { passive } \\
\text { demand }\end{array}$ & $\begin{array}{l}+ \text { heterogene- } \\
\text { ous products }\end{array}$ & $\begin{array}{l}+ \\
\text { no power }\end{array}$ & $\begin{array}{l}+ \\
\text { reduced } \\
\text { feedback }\end{array}$ \\
\hline $\begin{array}{l}\text { mean degree of } \\
\text { collusion }\end{array}$ & 55,90 & 60,93 & 60,93 & 65,00 & 65,00 & 25,00 \\
\hline $\begin{array}{l}\text { number of obser- } \\
\text { vations }\end{array}$ & 242 & 94 & 94 & 11 & 11 & 1 \\
\hline
\end{tabular}

Table 19

Progressive Reduction of Sample

\section{A Statistically Valid Indirect Approach}

While intuitive, the progressive reduction of the sample is statistically not valid. Yet there is a statistically correct, indirect way of using the data from the meta-study to make a contribution to the discussion of the Airtours case. It also pools the data, such that markets of up to three, and mar-

kets of at least four firms are lumped together. That way, one increases statistical power. In a second step, one introduces all features of the Airtours case on which there is experimental data as covariates into the statistical test (ANOVA). One tests whether the main effect remains significant, despite all these controls. As

Table 20 shows, this is indeed the case.

\begin{tabular}{|c|c|c|c|c|}
\hline covariates & feature & significance & \multicolumn{2}{|c|}{ mean degree of collusion } \\
\hline & strategic variable & $\mathrm{p}=0,001$ & & \\
\hline & $\begin{array}{c}\text { computer / human } \\
\text { buyer }\end{array}$ & $\mathrm{p}=0,004$ & & \\
\hline & $\begin{array}{c}\text { homogeneous / } \\
\text { substitute }\end{array}$ & $\mathrm{p}<0,001$ & & \\
\hline & power / no & $\mathrm{p}=0,016$ & & \\
\hline $\begin{array}{c}\text { main effect } \\
\text { controlled for all } \\
\text { covariates) }\end{array}$ & $\begin{array}{c}\text { number of } \\
\text { sellers }\end{array}$ & $\mathrm{p}=0,225$ & & market of $4-25$ \\
15,88
\end{tabular}

Table 20

Estimated Effect of Airtours Merger

adj. $R^{2}=0,439$

From this one may conclude that reducing the market from four to three increases collusion substantially. It is not possible, in a statistically valid way, to predict the absolute level of collusion, provided parameters are exactly as in the Airtours case. But the relative difference is safely established.

There still remains one challenge: there is no experimental data on open markets; and in the case, the reduction from four to three only describes what happened with the big, vertically fully integrated providers. But the difference in collusion between markets of 2-3 and markets of 4-25 is dramatic. One must be very optimistic about the power of fringe competition to believe that it reduces this difference to a normatively negligible size. Had the Commission checked the experimental evidence, it should have fared better in court. 


\section{Conclusion}

Unbeknownst to each other, experimental economics and antitrust law have for decades been working on the same issue: under which conditions is tacit collusion likely in narrow oligopoly? This is a prognostic task. The antitrust authorities are bound to make mistakes. Currently, the authorities combine a bottom up with a top down approach. They use checklists that summarize earlier case experience. And they rely on game theory. As this paper shows, there is a solid, third body of evidence. In cross-validating their estimations with the experimental evidence, the antitrust authorities are likely to reduce the error rate of merger control. 


\section{References}

Albors-Llorens, Albertina (2000). "Collective Dominance: a Mechanism for the Control of Oligopolistic Markets?" Cambridge Law Journal 59: 253-257.

Bertrand, Joseph Louis Francois (1883). "Théorie mathématique de la richesse sociale par León Walras. Recherches sur les principes mathématiques de la théorie des richesses par Augustin Cournot." Journal des savants 67: 499-508.

Briones, JuAn and Atilano Jorge Padilla (2001). "The Complex Landscape of Oligopolies under EU Competition Policy - Is Collective Dominance Ripe for Guidelines?" World Competition 24: 307-318.

Chamberlin, EdWARD (1933). The Theory of Monopolistic Competition. Cambridge, Harvard University Press.

Christensen, Peder and Valerie Rabassa (2001). "The Airtours (In Re Airtours/First Choice, Case IV/M.1524, (2000) O.J. L093/01) Decision: Is There a New Commission Approach to Collective Dominance?" European Competition Law Review 22: 227-237.

Cournot, ANTOINE-Augustin (1838). Recherches sur les principes mathématiques de la théorie des richesses. Paris,, Libraririe des sciences politiques et sociales M. Riveáre \& cie.

Diamond, Peter (1971). "A Model of Price Adjustments." Journal of Economic Theory 3: 156168.

Engel, Christoph (2007). "How Much Collusion? A Meta-Analysis on Oligopoly Experiments." Journal of Competition Law and Economics 3: ***.

ETTER, BORIS (2000). "The Assessment of Mergers in the EC under the Concept of Collective Dominance: an Analysis of the Recent Decisions and Judgments- by an Economic Approach." World Competition 23: 103-139.

Guerrero, Kevin (2003). "A New "Convincing Evidence" Standard in European Merger Review." University of Cincinnati Law Review 72: 249-284.

Haupt, Heiko (2002). "Collective Dominance Under Article 82 E.C. and E.C. Merger Control in the Light of the Airtours Judgment." European Competition Law Review 23: 434-444.

Ivaldi, Marc, Bruno Jullien, Patrick Rey, Paul Seabright and Jean Tirole (2003). The Economics of Tacit Collusio http://europa.eu.int/comm/competition/mergers/review/ the_economics_of tacit_collusion_en.pdf. 
KOKKORIS, IOANNIS (2005). "The Reform of the European Control Merger Regulation in the Aftermath of the Airtours Case- the Eagerly Expected Debate: SLC v Dominance Test." European Competition Law Review 26: 37-47.

Kreps, David M. and Jose Alexandre Scheinkman (1983). "Quantity Precommitment and Bertrand Competition Yields Cournot Outcomes." Bell Journal of Economics 14: 326-337.

Motta, Massimo (2000). "E.C. Merger Policy and the Airtours Case." European Competition Law Review 21: 199-207.

NiKPay, Ali and Fred Houwen (2003). "Tour de Force or a Little Local Turbulence? A Heretical View on the Airtours Judgment." European Competition Law Review 24: 193-202.

Overd, Alan (2002). "After the Airtours Appeal." European Competition Law Review 23: 375377.

Perez, Mercedes-Garcia (1998). "Collective Dominance under the Merger Regulation." European Law Review 23: 475-480.

Pflanz, Matthias (2005). "Oracle/PeopleSoft: the Economics of the EC Review." European Competition Law Review 26: 123-127.

SCOTT, ANDREW (2003). "'Winter Talk by the Fireside?": Tacit Collusion and the Airtours Case." Journal of Business Law: 298-314.

Spink, Paul and Chin Aun Ong (2003). "Lessons in Litigation: Collective Dominance and Merger Control- Airtours Plc V Commission of the European Communities." Juridical Review: 163-184.

StAcKelberg, Heinrich VON (1934). Marktform und Gleichgewicht. Wien und Berlin, J. Springer.

STROuX, SigRID (2002). "Collective Dominance under the Merger Regulation: a Serious Evidentiary Reprimand for the Commission." European Law Review 27: 736-746.

Veluanovski, Cento (2004). "EC Merger Policy after GE/Honeywell and Airtours." Antitrust Bulletin 49: 159-193.

YsewYn, Johan and Cristina CAFFARRA (1998). "Two's Company: Three's a Crowd: the Future of Collective Dominance after Kali and Salz Judgment (French Republic V. Commission (1998) 4 C.M.L.R. 829)." European Competition Law Review 19: 468-472. 